\title{
sciendo
}

\section{Effect of Implicit Voice Theories on Employee Constructive Voice and Defensive Silence: A Study in Education and Health Sector}

\author{
Safiye ŞAHIN ${ }^{1}$, Bilal ÇANKIR ${ }^{2}$, Bahar SEREZ ARSLAN ${ }^{3}$ \\ ${ }^{1}$ Istanbul Medeniyet University, Faculty of Health Sciences, Department of Healthcare Management, Istanbul, Tur- \\ key, safiye.sahin@medeniyet.edu.tr \\ ${ }^{2}$ Istanbul Medeniyet University, Faculty of Health Sciences, Department of Healthcare Management, Istanbul, Tur- \\ key, bilal.cankir@medeniyet.edu.tr \\ ${ }^{3}$ Kırklareli University, Healthcare Services Vocational School, Kırklareli, Turkey, bahar.serezarslan@klu.edu.tr
}

\begin{abstract}
Background and Purpose: Implicit voice theories are the beliefs that are related to employee silence. This study aims to examine the implicit voice theories (don't embarrass the boss in public, negative career consequences of voice) as predictors of employee defensive silence and employee constructive voice.

Methodology: This study is a cross-sectional and an analytical study. The sample of this study consisted of 494 participants working in the healthcare sector $(n=277)$ and education sector $(n=217)$ in Turkey. We performed linear regression analyses to test our hypotheses.

Results: We found that power distance and negative career consequences of voice predicted employee defensive silence while proactive personality and the belief of "don't embarrass the boss in public" predicted employee constructive voice. These results confirm the effect of implicit voice theories on employee silence and voice.

Conclusions: Employees holding the belief of "don't embarrass the boss in public" and "negative career consequences of voice" tend to remain silent or prefer to speak with their managers privately, which prevent sharing ideas in group interactions in organization. Therefore, managers must combat the belief that speaking up is risky. In order to change these beliefs in a positive way, they should make their subordinates feel that speaking up is a valuable behavior in organization.
\end{abstract}

Keywords: Implicit voice theories, Employee defensive silence, Employee constructive voice, Power distance, Proactive personality, Healthcare sector, Education sector

\section{Introduction}

In today's rapidly increasing competitive conditions, the need for employees who are committed to the organization and who show high performance is increasing. The way for businesses to cope with increasing competition will be possible if their employees are responsible, innovative and they constantly improve their work. For this, em- ployees should participate in the decision-making mechanisms, express their suggestions that will improve their work, and report the mistakes to the management. However, studies have shown that employees sometimes prefer to remain silent to speak up due to individual and organizational reasons (e.g., Chou and Chang, 2020; Takhsha, Barahimi, Adelpanah, and Salehzadeh, 2020). This situation that causes organizational silence and ways to prevent

Received: 30th April 2020; revised: 27th June 2021; accepted: 30th July 2021 
organizational silence are important issues for researchers and managers. This is because organizational silence has both negative effects on employees' work outcomes and also negatively affects organizational performance. There are many studies on the negative impact of organizational silence on employees. These studies confirm that organizational silence decreases employee commitment (Bayramoglu and Cetinkanat, 2020), creativity (Sadeghi and Razavi, 2020) and work engagement (Pirzada, Mirani, Phulpoto, Dogar, and Mahar, 2020; Singh, Singh, Ahmad, Singh, and Kaur, 2020). In addition, organizational silence has a negative impact on organizational performance as it reduces creativity and prevents employees' feedback on the benefit of the organization (Sadeghi and Razavi, 2020).

Many reasons for organizational silence, which has significant negative consequences for businesses and employees, have been documented in the previous literature. According to Chou and Chang (2020) and Zhan (2020), these are individual, interpersonal/interactional and organizational reasons. For individual reasons of organizational silence, lower conscientiousness trait, higher agreeable personality, and being introvert were found to be related to employee silence behavior (Lee, Diefendorff, Kim, and Bian 2014). On the contrary, being extravert, open to new experience, imaginative, proactive, and having creative personality traits are positively associated with employee voice behavior (Chou and Chang, 2020). For interpersonal/ interactional reasons, researchers focus on the interaction of employees with co-workers and managers. Employees may prefer to remain silent in order to prevent their relationships with colleagues to deteriorate. Takhsha, Barahimi, Adelpanah, and Salehzadeh (2020) indicated that employees could opt to remain silent due to employees' fear of being ostracized by their colleagues. Besides, Breevaart, Bohle, Pletzer, and Medina (2019) explain employee silence via COR (Conservation of Resources) theory. According to them, employees may prefer silence to voice in order to protect their personal resources, such as keeping good relationship with their colleagues. The other reason for interpersonal/interactional silence is leader-member interaction (Zhan, 2020). Previous studies have shown that poor relationship between employee and supervisor leads to employee silence (e.g. Ergül and Söyük, 2020; Xu, Zhao, Xi, and Li, 2020). Lastly, organizational climate, organizational culture, hierarchical structure of organization, level of centralization, and organizational policies are among the organizational reasons of employee silence (Chou and Chang, 2020).

Previous studies have gathered serious evidence about the individual, interpersonal / interactional, and organizational antecedents of organizational silence (e.g., Detert and Burris, 2007; LePine and Dyne, 2001). However, some other studies have focused on beliefs causing employee silence. Moreover, these researchers claim that these beliefs can prevent employee voice regardless of the presence of positive voice climate (Detert and Edmonson, 2011). Therefore, it is important to investigate these beliefs called implicit voice theories. Implicit voice theories are learned during ordinary life experiences, for example, at home and in hierarchical institutions such as schools and sports teams when responding to authorities such as parents, teachers, and coaches (Starbuck, 2016). Detert and Edmondson (2011, p.462) define implicit voice theories as "that largely taken-for-granted beliefs about the risk or inappropriateness of speaking up in hierarchical organizations".

Employees perceive speaking up as risky due to implicit voice theories, even though their organization and managers encourage them to speak up (Knoll, Neves, Schyns, and Meyer, 2020). Despite the importance of implicit voice theories in organizational silence literature, the studies about the effect of implicit voice theories on employee silence and voice are very limited. Therefore, this study aims to examine the effect of implicit voice theories on employee silence and employee voice in Turkish context.

This study is expected to contribute literature in several ways. First, we test the effect of implicit voice theories on employee defensive silence and employee constructive voice. Employee silence and employee voice are different constructs, which have been shown by previous literature (Dyne, Ang, and Botero, 2003; Sherf, Parke, and Isaakyan, 2020). The current study examines both employee silence and employee voice in order to conduct a comprehensive study on implicit voice theories and organizational silence literature. As mentioned before, there is a scarcity of studies about implicit voice theories. Therefore, this study is expected to contribute to the implicit voice theories by testing their effects on employee voice and employee silence in another country setting and other occupations such as healthcare and educational professionals.

\section{Background}

\subsection{Employee Defensive silence}

Employee silence has been defined as the employees' not expressing their opinions about organizational and job related issues intentionally (Morrison and Milliken, 2000). Employee silence is an intentional behavior in which individuals keep silence by not sharing their real thoughts about organizational issues with people who have the ability to make changes and corrections at the organizational level (Pinder and Harlos, 2001).

Employees remain silent, believing that it is not worth talking about the problems within the organization or that expressing their opinions will endanger them (Under and Gerede, 2021). Fear of receiving negative feedback from managers and avoiding opposing situations cause them to 
remain silent (Morrison and Milliken, 2000). This situation also causes employees not to share their ideas, opinions and information deliberately and can cause serious harm to them along with the organization. At the same time, employee silence leads to a decrease in the performance and efficiency of the organization.

Dyne, Ang, and Botero (2003) suggested that not all silence behaviors are passive behaviors and that employee silence should not be considered the opposite of employee voice. In addition, they stated that employee silence is a purposeful, motivated, active and conscious structure and therefore is of great importance. Based on this, they classified silence into three groups as "acquiescent silence", "defensive silence" and "prosocial silence" (Dyne, Ang, and Botero, 2003). In this study, only defensive silence will be examined. Dyne, Ang, and Botero (2003, p. 1367) defined defensive silence as "withholding relevant ideas, information, or opinions as a form of self-protection, based on fear". Employees who remain silent for defensive purposes actually do not always consider organizational activities appropriate. However, they do not express their views, believing that it would be unnecessary or harmful to their own interests (Pinder and Harlos, 2001).

\subsection{Employee Constructive Voice}

Employee voice is defined as the voluntary communication of ideas, suggestions, concerns and thoughts about work-related issues by employees in order to improve the functions of an organization or unit (Chamberlin, Newton, and Lepine, 2017; Morrison, 2014). Employee voice should be related to the working environment and conveyed to someone within the organization. Employee voice is not only verbal, but can also be delivered via e-mail and other communication channels (Cheng, Nudelman, Otto, and $\mathrm{Ma}, 2020$ ). A supervisor, a colleague or someone outside of the organization can be the target or receipt of the employee voice (Morrison, 2014). In the current study, we focused on upward and internal voice.

Researchers have made different classifications by stating that employee voice is a multidimensional construct (e.g. Liang, Farh, and Farh, 2012; Maynes and Podsakoff, 2014). We draw on classification of Maynes and Podsakoff (2014). According to Maynes and Podsakoff (2014), voice behavior has two main sub-dimensions as positive and negative voice. Positive voice refers to expressing innovative ideas for change and developing recommendations for standard processes even if others do not agree. Positive voice includes: (a) employees making recommendations about policies, programs, goals, processes relevant to their job; (b) defending the institution against unfounded criticism, (c) developing constructive suggestions for the growth of the institution and its activities to be carried out more effectively and efficiently; (d) volun- tarily sharing these views with colleagues and managers through various communication channels (Çankır, 2016; Maynes and Podsakoff, 2014). Positive voice behavior has two sub-dimensions as supportive and constructive voice. Within the scope of this study, only constructive voice will be examined.

Constructive voice is the voluntary expression of thoughts, knowledge or opinions focused on organizational functional change and affecting the work (Maynes and Podsakoff, 2014). Suggestions for improvement in the employee's standard work processes and suggesting ideas for new or more effective work methods can be given as examples of constructive voice (Maynes and Podsakoff, 2014).

\subsection{Implicit Voice Theories}

Yeager and Dweck (2012, p. 303) define implicit theories as "core assumptions about the malleability of personal attributes. They are called 'implicit' because they are rarely made explicit, and they are called 'theories' because like a scientific theory, they create a framework for making for prediction and judging the meaning of events in one's world." In other words, 'implicit' means that individuals do not need to test the accuracy of the information they obtain through social learning. 'Theory' means understanding the functioning of the social world in an abstract way. Implicit theories are knowledge structures that individuals use to adapt to their environment and understand the behavior of others (Knoll, Neves, Schyns, and Meyer, 2020). In addition, these knowledge structures have an effect on the actions of individuals. Thanks to this information, individuals give quick and relatively ready answers to the events. Implicit theories can also be used to explain social relationships (Engle and Lord, 1997). For example, Engle and Lord (1997) examined the leader-member exchange by using implicit theories. Similarly, Detert and Edmondson (2011) used implicit theories to explain the organizational silence. In their study, they stated that they were invited to explore the antecedents of employee silence by a high technology company. They conducted four studies to investigate the causes of employee silence. As a result of these studies, the implicit voice theories scale consisting of 5 sub-dimensions has developed (presumed target identification, need solid data or solutions to speak up, don't bypass the boss upward, don't embarrass the boss in public, and negative career consequences of voice) (Detert and Edmondson, 2011). Within the scope of this study, only the subscales of 'don't embarrass the boss in public' and 'negative career consequences of voice' were included.

Don't embarrass the boss in public: This sub-dimension refers to employees avoiding sharing their criticism, suggestions or ideas with their managers in front of the group and voicing them when they are alone with their 
managers. This sub-dimension means that employees believe that voicing their opinions within the group will embarrass their managers in front of the group or challenge their managers. Employees who think and believe in this way avoid expressing their opinions to their managers within the group. They think that they need to inform their managers about this issue beforehand in order to talk to their managers in the group, or if they have not had the opportunity to talk before, they believe that they should talk to their managers privately after the group meeting. The reason for this is that when they express their opinions directly within the group, they assume that their managers will not like this situation. However, this situation harms organizational learning in two ways. The first is to express their opinions within the group, allowing other group members to contribute on the subject. Second, if a decision needs to be made during the group meeting, the employee's retention of his/her opinion for later comment prevents his/her participation in the decision (Detert and Edmondson, 2011).

Employees holding the belief of don't embarrass the boss in public will not be inclined to voice their suggestions and opinions in meetings or in front of the group (Detert and Edmondson, 2011). The belief of don't embarrass the boss in public is rooted in the fear of showing disloyalty to the manager (Isaakyan, 2018). This belief also includes the assumption that voicing ideas or suggestion by employees means that managers are not capable of thinking or seeing these ideas or solutions about work. Therefore, employees having this belief presume that if they voice their suggestions or ideas about work to their managers, their managers feel themselves inadequate which turns into embarrassment for the managers. As a result of these assumptions, the belief of don't embarrass the boss in public leads to an increase in employee defensive silence while a decrease in employee constructive voice. Therefore, we set the hypothesis 1 and 2 as following:

H1: Employees with the belief of don't embarrass the boss in public will be more likely to choose defensive silence in order to avoid embarrassing their boss in front of others.

H2: Employees with the belief of don't embarrass the boss in public who think that raising voice might embarrass the boss in public will less often raise their voice on organizational issues in a constructive manner.

Negative career consequences of voice: This sub-dimension refers that employees believe that when they voice their thoughts, suggestions, or criticisms about the job or their organization, managers will not like it and will retaliate against them. In response to their criticism, employees believe that their managers may score low performance or they can prevent them from benefiting from promotions and awards by developing a negative attitude towards them. In addition, employees believe that voicing their criticism for the benefit of the organization will not be of any benefit to them and will have negative effects on their careers (Detert and Edmondson, 2011). For example, in Detert and Edmondson's (2011, p. 468) study, employees expressed their thoughts as follows:

"What good is it going to do me to stand up and have a legitimate question or maybe challenge them about something? Nothing but put me lower in the basement."

"My manager determines my destiny at this company, therefore I dare not challenge him and what he's telling me to do. So, in a sense, it's not safe to speak up."

"If I disagree, they would maybe hold that grudge against me-like our end-of-year review, they might be nit-picky."

In order to explain the consequences of expressing their job-related suggestions and criticisms, employees refer to their beliefs that they have gained through social learning (Glassenberg, 2012). These beliefs that speaking is risky may not always reflect the real situation. When Detert and Edmondson (2011) asked participants who believed that speaking was risky, whether they had experienced such a situation before, the participants stated that they mostly did not. On the contrary, some participants stated that their managers gave positive reactions when they expressed their criticism and suggestions. Despite this, it was found that their beliefs that speaking was risky did not change. This ultimately shows that these beliefs are difficult to change (Willemsma, 2014). Employees may be aware of their beliefs that speaking is risky, but may not be aware of the impact of these beliefs on their actions (Knoll et al., 2020). Therefore, employees who believe that speaking up is risky and leads negative career consequences are not eager to suggest new or challenging ideas to their managers. From this point, the hypothesis 3 and 4 are determined as following:

H3: Employees holding the belief of negative career consequences of voice will be more likely to remain silent in order to avoid the risks of speaking up, such as lower performance appraisal, promotion issues, etc.

H4: Employees who believe the negative career consequences of voice will be less likely to speak up constructively for development of their work and organization in order to protect themselves against the danger of speaking up.

\section{Methods}

\subsection{Sample and Procedure}

The sample of the study was composed of healthcare personnel and teachers in Turkey. The data were collected by survey method between May 1 and June 30, 2018. After receiving the necessary institutional permissions from the hospitals and schools in Edirne province, the respondents who accepted to participate in this research were given 
questionnaire forms. One week later, the questionnaire forms were collected. Two or three follow-up visits were made. A total of 503 questionnaires were returned. After the incomplete questionnaires were eliminated, 494 questionnaires were included in the study. In order to reach the ideal sample size, a sample size of 10-20 times the total scale items is calculated (Kline, 2016). There is a total of 35 items in the scale. The ideal sample size is determined to be at least 350-700. Therefore, the sample size of 494 participants is within ideal limits.

The sample consisted of a total of 494 participants working in the education sector $(n=217)$ and healthcare professionals working in hospitals $(n=277)$ in Edirne in Turkey. The characteristics of the sample are given in Table 1.

Table 1: Socio-demographic features of sample

\begin{tabular}{|l|c|c|c|c|c|c|}
\hline & \multicolumn{3}{|c|}{ Healthcare professionals } & \multicolumn{3}{c|}{ Education professionals } \\
\hline Variables & N & M & SD & N & M & SD \\
\hline Gender (1=Male) & 272 & 0.32 & 0.47 & 217 & 0.48 & 0.50 \\
\hline Marital status (1=Single) & 272 & 0.53 & 0.50 & 217 & 0.71 & 0.45 \\
\hline $\begin{array}{l}\text { Managerial position } \\
\text { (1=Manager) }\end{array}$ & 270 & 0.11 & 0.31 & 217 & 0.10 & 0.30 \\
\hline Age & 272 & 32.17 & 8.10 & 217 & 35.53 & 9.18 \\
\hline Organizational tenure & 270 & 6.77 & 6.29 & 215 & 4.84 & 4.44 \\
\hline
\end{tabular}

Note: N: Number; M: Mean; SD: Standard Deviation.

\subsection{Data collection tool}

The first part of the questionnaire includes socio-demographic questions for the participants. The other parts of questionnaire form consist of scales validated by previous studies. Information about the scales are given below. All of these scales are 5-point Likert type scales $(1=$ Strongly Disagree, 5 = Strongly Agree).

\subsubsection{Independent variables}

Implicit voice theories scale: The implicit voice theories scale, which was developed by Detert and Edmondson (2011) and adapted to Turkish within the scope of this study, was used to study its validity and reliability. This scale consists of five dimensions (presumed target identification, need solid data or solutions to speak up, don't bypass the boss upward, don't embarrass the boss in public, and negative career consequences of voice) and a total of 20 items. Each dimension consists of 4 items. This is a five-point Likert-type scale $(1=$ Definitely disagree to $5=$ Definitely agree) originally. Detert and Edmondson (2011) tested the validity of the scale with the structural equation program. As a result of the Confirmatory Factor Analysis (CFA), they found the fit indices of the five-factor scale were within acceptable limits $(\mathrm{RMSEA}=.05, \mathrm{CFI}=.97$,
NNFI $=.96$, in Study 3, p.473). Cronbach Alpha coefficients of the scale were reported to be greater than 0.70 (Detert and Edmondson, 2011).

A translation and back-translation procedure was used to adapt this scale to Turkish (Brislin, 1970). First, the scale was translated into Turkish by two researchers with a $\mathrm{PhD}$ in Business Management and Organization. It was checked by a professional translator. Then it was checked again by a faculty member who is an Associate Professor in the field of Organizational Behavior. The scale translated in Turkish was translated back from Turkish to English by another translator. The new translation was checked by comparing the original of the scale. It was checked in terms of grammar by a lecturer with a PhD in Turkish Language and Literature. Finally, a pilot study was conducted with 30 participants. As a result of the pilot study, only the first item of the "don't embarrass the boss in public" sub-dimension was revised and a pilot study was made with 10 participants again. As a result of pilot studies, it was determined that there was no unclear item in the scale.

The first questionnaire form consisted of 5 sub-dimensions and 20 items of implicit voice theories and 27 items of other variables (proactive personality: 10 items, power distance: 7 items, employee defensive silence: 5 items, and employee voice: 5 items). When the surveys were distributed, we received feedback from respondents that the survey form was too long. They stated that they 
had difficulty answering the items of implicit voice theories and demanded that the number of items be reduced. In the first polls returned, it was noticed that the implicit voice theories items were left blank. For this reason, only two dimensions of the implicit voice theories scale (don't embarrass the boss in public and negative career consequences of voice) were included in the study.

Don't embarrass the boss in public: According to this sub-dimension, employees believe that expressing their ideas, suggestions or criticism about the job or organization during meetings or group dialogues will put the manager in a difficult situation (Detert and Edmondson, 2011). This sub-dimension consists of 4 questions. One of the sample items in this sub-scale is "Pointing out problems or inefficiencies in front of others is likely to embarrass the boss". Cronbach Alpha coefficient was reported as 0.76 (Detert and Edmondson, 2011).

Negative career consequences of voice: In this sub-dimension, employees believe that when they voice a job-related suggestion or criticism, they will be exposed to a negative reaction from their managers. Therefore, they think that their careers will be negatively affected (Detert and Edmondson, 2011). An example item is "Pointing out problems, errors, or inefficiencies might very well result in lowered job evaluations". The Cronbach Alpha coefficient of this sub-dimension consisting of 4 questions was reported as 0.76 (Detert and Edmondson, 2011).

\subsubsection{Dependent variables}

Employee constructive voice: The constructive voice subscale developed by Maynes and Podsakoff (2014) was used. This subscale was adapted to Turkish by Çankır (2016). It consists of 5 items. Maynes and Podsakoff (2014) reported the Cronbach Alpha coefficient of this sub-dimension as 0.95. Çankır (2016) stated that the Cronbach Alpha coefficient of this sub-dimension is greater than 0.70 . "Frequently makes suggestions about how to improve work methods or practices" is one of the sample items in this scale.

Employee defensive silence: Defensive silence sub-dimension consisting of 5 questions was used in the scale developed by Dyne, Ang and Botero (2003) and adapted to Turkish by Erdoğan (2011). Erdoğan (2011) stated that the Cronbach Alpha coefficient of this sub-dimension is 0.853 . A sample item is "This employee avoids expressing ideas for improvements, due to self-protection".

\subsubsection{Control variables}

Proactive personality: Proactive personality refers to the individual's ability to initiate the change he / she deems necessary without any demand (Bolino, Valcea, and
Harvey, 2010). Proactive individuals take the opportunity, take initiative, take action and persistently make an effort until meaningful change is achieved (Bateman and Crant, 1993). Individuals who create a positive change in their environment without being affected by the obstacles in the environment are called proactive persons (Seibert et al., 2001). It is also one of the most important predictors of proactive behavior (Crant, 2000). Employee constructive voice is also defined as a part of proactive behavior (e.g. Morrison, 2014; Liang, Farh, and Farh, 2012). Both concepts include challenging the status quo (Crant, 2000). Therefore, proactive employees whose nature is to challenge the status quo will be less likely to remain silent in discussing organizational issues and will be more likely to engage in constructive speaking up activities, such as coming up with a new idea or suggestions related to development of their work or organization. In previous studies, proactive personality has been determined as a control variable for employee voice (Detert and Edmondson, 2011).

A unidimensional scale consisting of 10 questions developed by Bateman and Crant (1993) and adapted to Turkish by Akın and Arıcı (2015) was used to measure proactive personality. "I am constantly looking out for new ways to improve my life" is one of the sample items in this scale. In the reliability analysis of the scale, the Cronbach Alpha reliability coefficient was found to be 0.86 (Akın and Arıc1, 2015).

Power distance: Power distance is a cultural sub-dimension that deals with the fact that all individuals in the society are not equal and explains the attitude towards these power inequalities. Power distance is defined as the less powerful members of institutions and organizations in a country expecting and accepting the unequal distribution of power. It shows that inequality in a society is approved by followers as well as leaders (Hofstede, 1983). High power distance causes high and rigid hierarchy within the organization and reduces upward communication. This communication problem prevents employees from expressing their views and opinions about opportunities, problems and concerns (Morrison and Rothman, 2009). Employees perceiving high power distance in their organizations will be more likely to remain silent and will be less likely to speak up in a constructive manner in the organizations with high power distance that causes communication problems.

A uni-dimensional scale consisting of 7 questions developed by Arıkan (2011) was used to measure power distance. A sample item is "Speaking up with high-status people in this workplace is not easy". Arıkan (2011) reported the reliability coefficient of the scale as 0.85 .

Demographics and occupational variables: Sector, gender, age, organizational tenure, and managerial position were determined as control variables. These variables were converted into dummy codes (e.g., sector: $1=$ healthcare, $0=$ education; gender: $1=$ male, $0=$ female). All dum- 
my codes are shown in Table 4. According to the previous studies, these variables have significant effects on employee silence and employee voice (Detert and Burris 2007; Morrison, 2014). For example, employees having a longer tenure, may feel more organization-based self-esteem which leads to more speaking up than new recruits (Pierce and Gardner, 2004). Similarly, age is also related with employee voice (Cooper, 2018). According to Detert and Burris (2007), women are more inclined than men to suppress their feelings. Harmanci-Seren et al. (2018) found that the managerial position was significantly related with employee silence.

\subsection{Data Analysis}

SPSS 22 and LISREL 8.80 programs were used to analyse the data. First of all, skewness and kurtosis values were examined from the descriptive data of the scale averages to determine the normal distribution. According to Kline (2016), the skewness value should not be over \pm 3 and the kurtosis value should not be over \pm 10 , as an indicator of the normal distribution. It was determined that the data were normally distributed and therefore suitable for parametric analyses. The convergent validity and discriminant validity of the scales were analysed by Confirmatory Factor Analysis (CFA). Predictive validity was tested by linear regression analyses. To report the model fit, $\mathrm{X}^{2} / \mathrm{df}$ (Chi-square /degree of freedom), RMSEA (Root Mean Square Error of Approximation), NFI (Normed Fit Index), NNFI (Non-normed Fit Index), CFI (Comparative Fit Index) GFI (Goodness-of-fit Index) were used. Table 2 shows the range of values for these indexes which indicate a good fit (Hair et al., 2010; Kline, 2016).

In order to test the effect of independent variables on dependent variables, linear regression analysis was performed. Before performing the regression analyses, multicollinearity was checked by examining the Variance Inflation Factor (VIF) which is one of the indicators of multicollinearity (Yoo et al, 2014). VIF should be less than 10 (Yoo et al, 2014). In the current study, we found that VIF values were within the range of 1.069-1.274. Therefore, we can infer that multicollinearity does not exist in our study. Then we controlled the sector, age, gender, organizational tenure, and managerial position.

\section{Results}

\subsection{Results of the Validity and Reliability Analysis of the Scales}

Validity analysis of the scales was analysed with the LISREL 8.80 program. As a result of the first CFA, items with very low factor loadings $(<0.50)$ were deleted in order to increase the goodness of fit of the model. The deleted items are as follows: three items from proactive personality, three items from power distance, two items from employee constructive voice, one item from don't embarrass the boss in public, one item from negative career consequences of voice, and one item from employee defensive silence. As a result of the CFA analysis repeated after the items with low factor loadings were deleted, the measurement model showed good fit with the data (Table 2).

Table 2: Fit indexes of the measurement model as a result of the CFA

\begin{tabular}{|c|c|c|c|}
\hline Fit Indices & Measurement model & Good Fit & Acceptable Fit \\
\hline $\mathrm{X}^{2} / \mathrm{df}$ & 1.83 & $0-2$ & $2.0-5.0$ \\
\hline RMSEA & 0.04 & $0-0.05$ & $0.05-0.08$ \\
\hline $\mathrm{NFI}$ & 0.95 & $0.95-1$ & $0.90-0.95$ \\
\hline $\mathrm{NNFI}$ & 0.97 & $0.97-1$ & $0.95-0.97$ \\
\hline CFI & 0.97 & $0.97-1$ & $0.95-.97$ \\
\hline GFI & 0.93 & $0.95-1$ & $0.90-0.95$ \\
\hline
\end{tabular}

Note: $\mathrm{X}^{2} / \mathrm{df}$ (Chi-square /degree of freedom), RMSEA (Root Mean Square Error of Approximation), NFI (Normed Fit Index), NNFI (Nonnormed Fit Index), CFI (Comparative Fit Index) GFI (Goodness-of-fit Index) 
According to Hair et al. (2010), in order to analyze the convergent validity of the scales, firstly all factor loads should be statistically significant and the standardized parameter estimates of the factor load should be above 0.50 ( $>0.70$ is ideal). Second criterion of convergent validity is the composite reliability $(\mathrm{CR})$ of variables $>0.60(\mathrm{Ba}-$ con, Sauer, and Young, 1995). Finally, average variance extracted (AVE) value should be higher than 0.50. AVE refers to the mean variance extracted for the items loading on a construct (Fornell and Larcker, 1981). Table 3 shows the standardized loadings, composite reliability, and AVE values of study variables.

Composite reliability and AVE values were found to be higher than 0.70 which indicates having convergent validity for all variables except proactive personality and power distance. Proactive personality and power distance had
AVE values lower than 0.50. Fornell and Larcker (1981) suggest that AVE value lower than 0.50 can be acceptable if the CR value is higher than 0.70 . Therefore, we can infer that all scales of this study have convergent validity. Then we checked the discriminant validity of scales. To do this, we analyzed the correlation coefficients of variables, which should be lower than 0.85 (Kline, 2016). In Table 4, the significant correlation coefficients (r) were between 0.172 and 0.510 . Therefore, this result shows that the scales in the study have discriminant validity.

In addition, in Table 3, Cronbach alpha values of all scales were found to be higher than 0.70 indicating all scales have high internal consistency (Cronbach, 1951). For example, Cronbach alpha's value was found to be 0.79 for don't embarrass the boss in public while it was found to be 0.80 for negative career consequences.

Table 3: Standardized Loadings, CR and AVE Coefficients of the Measurement Model

\begin{tabular}{|c|c|c|c|c|c|}
\hline Variables & $\begin{array}{c}\text { Standardized Load- } \\
\text { ings* }\end{array}$ & Error & $\begin{array}{l}\text { Composite Reli- } \\
\text { ability (CR) }\end{array}$ & $\begin{array}{c}\text { Square of } \\
\text { Standardized } \\
\text { Loadings }\end{array}$ & $\begin{array}{l}\text { Average Variance } \\
\text { Extracted } \\
\text { (AVE) }\end{array}$ \\
\hline \multirow{7}{*}{ Proactive personality } & 0.60 & 0.65 & 0.841 & 0.36 & 0.43 \\
\hline & 0.57 & 0.67 & & 0.32 & \\
\hline & 0.55 & 0.69 & & 0.30 & \\
\hline & 0.68 & 0.55 & & 0.46 & \\
\hline & 0.54 & 0.71 & & 0.29 & \\
\hline & 0.58 & 0.67 & & 0.34 & \\
\hline & 0.62 & 0.62 & & 0.38 & \\
\hline \multirow{4}{*}{ Power distance } & 0.72 & 0.47 & 0.792 & 0.52 & 0.49 \\
\hline & 0.69 & 0.52 & & 0.48 & \\
\hline & 0.72 & 0.47 & & 0.52 & \\
\hline & 0.65 & 0.57 & & 0.42 & \\
\hline \multirow{3}{*}{$\begin{array}{l}\text { Don't embarrass the } \\
\text { boss in public }\end{array}$} & 0.66 & 0.56 & 0.789 & 0.44 & 0.56 \\
\hline & 0.82 & 0.33 & & 0.67 & \\
\hline & 0.75 & 0.44 & & 0.56 & \\
\hline \multirow{3}{*}{$\begin{array}{l}\text { Negative career conse- } \\
\text { quences of voice }\end{array}$} & 0.74 & 0.45 & 0.810 & 0.55 & 0.59 \\
\hline & 0.82 & 0.33 & & 0.67 & \\
\hline & 0.74 & 0.45 & & 0.55 & \\
\hline \multirow{4}{*}{$\begin{array}{l}\text { Employee defensive } \\
\text { silence }\end{array}$} & 0.77 & 0.41 & 0.850 & 0.59 & 0.58 \\
\hline & 0.65 & 0.58 & & 0.42 & \\
\hline & 0.83 & 0.32 & & 0.69 & \\
\hline & 0.80 & 0.36 & & 0.64 & \\
\hline \multirow{3}{*}{$\begin{array}{l}\text { Employee constructive } \\
\text { voice }\end{array}$} & 0.8 & 0.35 & 0.878 & 0.64 & 0.71 \\
\hline & 0.86 & 0.27 & & 0.74 & \\
\hline & 0.86 & 0.26 & & 0.74 & \\
\hline
\end{tabular}

Note: *All item loadings were found to be significant 
Table 4: Means, Standard Deviations, Coefficients Alphas, and Correlations Between Study Variables

\begin{tabular}{|c|c|c|c|c|c|c|c|c|c|c|c|c|c|c|}
\hline & Variables & M & SD & 1 & 2 & 3 & 4 & 5 & 6 & 7 & 8 & 9 & 10 & 11 \\
\hline 1 & $\begin{array}{l}\text { Sector } \\
\text { (1=healthcare) }\end{array}$ & 0.56 & 0.50 & & & & & & & & & & & \\
\hline 2 & $\begin{array}{l}\text { Gender } \\
(1=\text { male })\end{array}$ & 0.39 & 0.49 & $-.163^{* *}$ & & & & & & & & & & \\
\hline 3 & Age & 33.77 & 8.63 & $-.191^{* *}$ & $.159 * *$ & & & & & & & & & \\
\hline 4 & $\begin{array}{l}\text { Organizational } \\
\text { tenure }\end{array}$ & 5.91 & 5.61 & $.171^{* *}$ & -0.01 & $.531^{* *}$ & & & & & & & & \\
\hline 5 & $\begin{array}{l}\text { Managerial } \\
\text { position } \\
\text { (1=manager) }\end{array}$ & 0.11 & 0.31 & .02 & $.090 *$ & $.095^{*}$ & $.090 *$ & & & & & & & \\
\hline 6 & $\begin{array}{l}\text { Don't embar- } \\
\text { rass the boss in } \\
\text { public }\end{array}$ & 3.43 & .90 & $.091^{*}$ & -.02 & -.02 & .022 & .002 & (.79) & & & & & \\
\hline 7 & $\begin{array}{l}\text { Negative career } \\
\text { consequences } \\
\text { of voice }\end{array}$ & 2.78 & 1.01 & $.152^{* *}$ & -.01 & -0.03 & .049 & .088 & $.172^{* *}$ & $(.80)$ & & & & \\
\hline 8 & $\begin{array}{l}\text { Proactive } \\
\text { personality }\end{array}$ & 3.84 & 0.58 & $-.095^{*}$ & .03 & 0.06 & -0.06 & .05 & $.254^{* *}$ & .04 & $(.79)$ & & & \\
\hline 9 & Power distance & 2.76 & 1.14 & $.378 * *$ & $-.137 * *$ & -.055 & $.123^{* *}$ & .063 & $.195^{* *}$ & $.369 * *$ & .022 & $(.76)$ & & \\
\hline 10 & $\begin{array}{l}\text { Employee } \\
\text { constructive } \\
\text { voice }\end{array}$ & 3.46 & 0.83 & -.025 & .02 & .03 & -0.03 & $.091^{*}$ & $.209 * *$ & .031 & $.351 * *$ & .007 & $(.88)$ & \\
\hline 11 & $\begin{array}{l}\text { Employee de- } \\
\text { fensive silence }\end{array}$ & 2.44 & 0.92 & $.348^{* *}$ & -.018 & .014 & $.108^{*}$ & $.116^{*}$ & $.187^{* *}$ & $.510 * *$ & -.02 & $.431^{* *}$ & -.035 & $(.84)$ \\
\hline
\end{tabular}

$* \mathrm{p}<.05 . * * \mathrm{p}<.01$. Coefficients alphas are along the diagonal in the parenthesis.

\subsection{Descriptive Data of Variables, Relationships Between Variables and Coefficients of Cronbach Alphas}

According to Table 4, dimension of don't embarrass the boss in public was significantly and positively correlated with the dimension of negative career consequences $(\mathrm{r}=0.172, \mathrm{p}<0,01)$, proactive personality $(\mathrm{r}=0.254, \mathrm{p}<0,01)$, power distance $(\mathrm{r}=0.195, \mathrm{p}<0,01)$, employee constructive voice $(r=0.209, p<0,01)$, and employee defensive silence $(r=0.187, p<0,01)$. However, the dimension of negative career consequences of voice was significantly and positively correlated with power distance $(r=0.369, \mathrm{p}<0,01)$ and employee defensive silence $(r=0.510, p<0,01)$. While proactive personality was significantly and positively correlated with employee constructive voice $(r=0.351, \mathrm{p}<0,01)$, power distance was significantly and positively correlated with employee defensive silence $(r=0.431, p<0,01)$.

The average mean of power distance, don't embarrass the boss in public, negative career consequences of voice and defensive silence behavior were found to be significantly higher in healthcare sector than in the education sector $(\mathrm{p}<0,05)$. While the average of proactive personality was significantly higher in the education sector than the healthcare sector $(p<0,05)$, the average of the voice behavior did not differ significantly compared to the sector $(\mathrm{p}>0,05)$.

\subsection{Results of regression analyses}

Table 5 demonstrates the results of linear regression analyses. The effect of control variables on employee defensive silence and employee constructive voice is given in Model 1. According to the Model 1, employee defensive silence was predicted by sector $(\beta=0.25, \mathrm{p}<0.01)$ and power distance $(\beta=0.35, \mathrm{p}<0.01)$ positively and significantly. $24 \%$ of the variance of employee defensive silence was explained by the sector and power distance $\left(\mathrm{R}^{2}=0.24\right)$. Meanwhile, only proactive personality $(\beta=0.34, p<0.01)$ predicted the employee constructive voice positively and significantly. Proactive personality explained the $13 \%$ of the variance of employee constructive voice $\left(R^{2}=0.13\right)$.

Model 2 shows the effect of implicit voice theories (don't embarrass the boss in public- DEB and negative career consequences of voice- NCCV), proactive personality, and power distance on employee defensive silence and employee constructive voice, as well as control variables. Employee defensive silence was predicted signif- 
icantly and positively by sector $(\beta=0.24, \mathrm{p}<0.01)$, power distance $(\beta=0.19, \mathrm{p}<0.01)$, DEB $(\beta=0.08, \mathrm{p}<0.01)$, and $\operatorname{NCCV}(\beta=0.39, \mathrm{p}<0.01)$. While these predictors explained the $38 \%$ of the variance of employee defensive silence $\left(\mathrm{R}^{2}=0,38\right)$, only DEB and NCCV explained the $14 \%$ of the variance of employee defensive silence $\left(\Delta R^{2}=0.14\right)$. Therefore, H1 and H3 were supported. Employee constructive voice was predicted by proactive personality $(\beta=0.31, p<0.01)$ and DEB $(\beta=0.12, p<0.01)$ significantly and positively. We found that DEB explained only $\% 2$ of the variance of employee constructive voice $\left(\Delta R^{2}=0.02\right)$. While H2 was rejected, we found support for opposite of our assumption, which indicates DEB has positive effect on employee constructive voice. NCCV had no significant effect on employee constructive voice $(p>0.05)$. Therefore, $\mathrm{H} 4$ was rejected. The summary of hypotheses is given in Table 6.

Table 5: Results of the regression analysis about the effect of implicit voice theories on employee constructive voice and employee defensive silence

\begin{tabular}{|c|c|c|c|c|}
\hline & \multicolumn{2}{|c|}{ Model 1} & \multicolumn{2}{|c|}{ Model 2} \\
\hline Variables & Defensive silence & Constructive Voice & Defensive silence & Constructive Voice \\
\hline Sector (1=healthcare) & $.25 * *$ & .03 & $.24^{* *}$ & .03 \\
\hline Gender (1=male) & .048 & .003 & .030 & .005 \\
\hline Age & .082 & .030 & .098 & .015 \\
\hline Organizational tenure & -.026 & -.036 & -.034 & -.047 \\
\hline Managerial position ( $1=$ manager) & .077 & .095 & .057 & .100 \\
\hline Proactive personality & -.011 & $0.34 * *$ & -.056 & $.31 * *$ \\
\hline Power distance & $.35 * *$ & -.014 & $.19 * *$ & -.041 \\
\hline \multicolumn{5}{|l|}{ Implicit voice theories } \\
\hline $\begin{array}{l}\text { Don't embarrass the boss in public } \\
\text { (DEB) }\end{array}$ & & & $.08^{*}$ & $.12 * *$ \\
\hline $\begin{array}{l}\text { Negative career consequences of } \\
\text { voice (NCCV) }\end{array}$ & & & $.39 * *$ & .003 \\
\hline $\mathrm{R}^{2}$ & 0.24 & 0.13 & 0.38 & 0.15 \\
\hline$\Delta \mathrm{R}^{2}$ & & & 0.14 & 0.02 \\
\hline
\end{tabular}

Note: Standardized regression coefficients are reported.

For the model 2 change in $\mathrm{R}^{2}\left(\Delta \mathrm{R}^{2}\right)$, the baseline model is model 1;

* p .05 and ** p .01 
Table 6: The summary of hypothesesployee defensive silence

\begin{tabular}{|l|l|}
\hline Hypotheses & Supported/Rejected \\
\hline $\begin{array}{l}\text { H1: Employees with the belief of don't embarrass the boss in public will } \\
\text { be more likely to choose defensive silence in order to avoid embarrassing } \\
\text { their boss in front of other employees. }\end{array}$ & Supported \\
\hline $\begin{array}{l}\text { H2: Employees with the belief of don't embarrass the boss in public that } \\
\text { raising voice might embarrass the boss in public will less often raise their } \\
\text { voice on organizational issues in a constructive manner. }\end{array}$ & Supported as opposite of our assumption \\
\hline $\begin{array}{l}\text { H3: Employees holding the belief of negative career consequences of voice } \\
\text { will be more likely to remain silent defensively in order to avoid the risks of } \\
\text { speaking up, such as lower performance appraisal, promotion issues, etc. }\end{array}$ & Supported \\
\hline $\begin{array}{l}\text { H4: Employees who believe the negative career consequences of voice will } \\
\text { less likely to speak up for development of their work and organization in } \\
\text { a constructive manner in order to protect themselves against the danger } \\
\text { of speaking up. }\end{array}$ & Rejected \\
\hline
\end{tabular}

\section{Discussion}

Organizations are well aware that employee participation is critical for organizational development. Employees can promote their organizations by suggesting new ideas or sharing their opinions. Thus, managers make efforts to create an environment that encourages employee voice. However, Detert and Edmondson (2011) have shown that employees may remain silent despite the presence of encouraging voice environment due to their beliefs that speaking is risky. These beliefs called implicit voice theories are the one of predictors of employee silence. However, there is a scarcity of studies investigating the role of implicit voice theories in employee silence and employee voice. Therefore, first contribution of this study is to provide empirical evidence about the implicit voice theories with employee silence and employee voice literature by testing the effect of implicit voice theories on employee defensive silence and employee constructive voice in Turkish sample consisting of two different sectors' employees. This study has also replicated the Detert and Edmondson's (2011) study and has confirmed their results in a different country whose culture is slightly different from USA.

The second contribution of this study is to examine the effect of two sub dimensions of implicit voice theories on employee silence and employee voice, which enables to extend the literature by examining both constructs as dependent variables. Our results have shown that the effect of each sub dimension of implicit voice theories can differ according to the employee voice behaviour or employee silence. In our study, don't embarrass the boss in public had significant and positive effect on employee constructive voice and on employee defensive silence. While negative career consequences of voice had significant and negative effect on employee defensive silence, it did not have significant effect on employee voice. These results may provide more empirical evidence that employee voice and employee silence are separate constructs and their predictors can be different. Therefore, managers and future researchers should investigate the factors related to employee silence and employee voice separately. From this point, not only managers should attempt to eliminate the factors causing employee silence in organizations, such as high level of power distance, but they should also create an organizational climate that encourages employees to speak up. Future researchers are encouraged to investigate which sub-dimension of implicit voice theories has significant effect on employee silence and employee voice separately.

Third, we controlled the effect of personal and organizational factors, as well as demographic and occupational features to test our research model. Controlling variables affecting employee voice and silence enables us to improve predicting the roles of implicit voice theories on employee defensive silence and employee constructive voice. Previous studies also suggest to consider power distance and proactive personality as control variables for employee voice and employee silence (Amah and Oyetuunde, 2020; Tedone and Bruk-Lee, 2021). Thus, our study responded the call of these studies. Another contribution of this study is to test the validity and reliability analysis of two sub-dimensions of implicit voice theories scale (“don't embar- 
rass the boss in public" and "negative career consequences of voice") which was developed by Detert and Edmondson (2011) in the context of Turkey. Thus, one of the antecedents of organizational silence can be examined in Turkey via this scale.

In the current study, we found that sector, power distance, don't embarrass the boss in public, and negative career consequences of voice predicted employee defensive silence significantly. However, don't embarrass the boss in public had positive and significant effect on employee defensive silence, its standardized $\beta$ coefficient was 0.08 , which indicates a minimum effect. Previous studies also have found the belief of don't embarrass the boss in public and negative career consequences of voice as a predictor of employee silence. For example, Under and Gerede, (2021) and Milliken et al. (2003) stated that fear is one of the most important factors in employee silence. According to the qualitative study conducted with forty employees by Milliken et al. (2003), the main reasons why the employees avoid expressing their opinions about the problems are their fear and their beliefs based on these fears. It is stated that employees are generally not willing to share information that can be perceived as a threat or negativity by the managers. Therefore, employees keep silent in order to avoid being known as the person who creates problems or constantly complains (Milliken et al., 2003).

Bowen and Blackmon (2003) also reported that employees could remain silent about the issues that their managers would not want to hear due to fear of punishment or reprisals. In line with these studies, Harmanc1 Seren et al, (2018), Alparslan, Cem, and Erdem, (2015), Ajay (2015) reported that participants opted to remain silent, because they believed that if they spoke up, they would find themselves in difficult situation such as working overload or night shifts, the possibility to be sent to another unit, loss of job, and getting unfair performance appraisal.

Detert and Edmondson (2011), in a study conducted with 231 participants in Northeast America, concluded that implicit voice theories predicted employee silence. This result indicates that employees holding implicit voice theories tend to avoid speaking against a leader. It is logical for employees to think that criticizing their manager within the group would endanger their career. Hence, they put themselves in a passive and silent position.

In addition, Pinder and Harlos (2001) stated that the individuals deliberately choose to remain silent because they are afraid of the possible consequences of voice. It can be asserted that employees who remain silent for defensive purposes do not actually accept organizational decisions as they are, but think that it will be unnecessary or harmful for their own interests to declare their opinions. Therefore, our result that the belief of the negative career consequences of voice predicted the employee defensive silence is in line with the previous literature.

Another result of this study is that power distance has a significant effect on employee defensive silence. This result is also supported by previous studies. For example, Huang et al. (2005), in a study conducted with 421 companies operating in 24 countries, found that the employee constructive voice and employee silence differed significantly according to the cultural perception of the countries. In their study, power distance was evaluated according to countries and it was determined that participants in countries with lower power distances expressed the problems more. In countries with a high power distance, it was stated that employees could remain silent to protect themselves (Huang et al.2005). Therefore, our results regarding power distance support previous literature.

Another dependent variable of this research, employee constructive voice is predicted significantly and positively by proactive personality and the belief of don't embarrass the boss in public. The result about belief of don't embarrass the boss in public is opposite of our hypothesis (H2) which indicated negative effect of this belief on employee constructive voice. Employees holding the belief of don't embarrass the boss in public believe that it should be privately communicated to the manager before voicing an idea in front of the group. In this way, they will avoid challenging the manager (Detert and Edmondson, 2011). Therefore, these employees may avoid speaking up about their suggestions with their manager in the meetings or in front of other employees. However, they may choose to speak up with their managers privately (Isaakyan, 2018). According to Isaakyan (2018), when employees speak up with their managers privately, they can inform their managers about their thoughts. By doing so, they may prove their loyalty to their managers and avoid negative career consequences of public voice. Isaakyan (2018) found supporting results that implicit voice theories had negative effect on public voice while these beliefs had positive effect on private voice. However, implicit public voice theories did not have significant effect on voice frequency in her study (Isaakyan, 2018). In our study, the scale of constructive voice behavior was used (Maynes and Podsakoff, 2014). Items in this scale do not contain information about speaking with the manager in a group or in private. Therefore, based on this unexpected result, we can assume that employees might have expressed their opinions to their managers in more private environments. For future studies, it is also recommended to examine the effect of implicit voice theories on the type of voice (private or public).

Also, the proactive personality is found to be one of the significant predictors of employee voice. This result is also in line with previous studies. In a study conducted in Indonesia by Wijaya (2019), two surveys of approximately 12,000 university graduates were conducted at 4-month intervals. The results of this research reveal the positive relationships between proactive personality and employee voice. Proactive individuals are already active, lively and energetic people. These people, who reflect their ener- 
gies, criticism, reaction and other negative developments as well as their positive emotions, become more successful in their careers (Seibert et al., 1999). According to the research conducted by Bakker, Tims, and Derks (2012), employees with proactive personality can increase the resources that will motivate them by shaping their own work environment and can set new challenging goals for themselves. In order to achieve these goals, they will prefer to speak out regarding organizational policies. Our results support these studies.

As a result of this study, employees are less likely to speak up with their managers for suggesting new ideas or voicing their opinions which can improve the organizational process due to their fear of negative career consequences of voice and embarrassing their boss in front of others. Therefore, managers should be aware of their subordinates' fear about speaking up. Employees can be encouraged by rewarding when they come out with new ideas, suggestions or concerns. Especially, these rewards may be psychological support or constructive feedback to employees' voicing (). Managers should create encouraging voice climate in their organizations by making sure employees' speaking up is a desirable behavior and has positive outcomes in the organization.

With this study, we expect to contribute to the existing literature regarding implicit voice theories, employee silence and employee voice. However, this study has also some limitations. First limitation of the study is its cross-sectional design. In studies with cross-sectional design, the ability to make inferences about causality between the independent and dependent variables may be limited due to collecting data at one point. This is because it is not possible to measure the effect of the independent variable on the dependent variable over time, and therefore causality cannot be determined with certainty (Antonakis et al., 2010). Therefore, future researchers are recommended to examine the predictor role of implicit voice theories on employee silence and voice based on longitudinal data.

Second limitation is the common method problem, which occurs when the data for independent and dependent variables are gathered from the same source and at the same time point. In the current study, data were only collected from employees. This situation may cause the autocorrelation problem which indicates there is a significant relationship between the variables even if the significant relationship does not exist due to the respondent's tendency to rate the items of scales the same (Podsakoff et al., 2003). It was not possible to eliminate negative effect of common method bias completely, however, the effect of common method variance was minimized by the rigorous procedural and statistical methodologies that we used in our study. To eliminate this problem, future researchers are recommended to obtain data from different sources such as employees, supervisors, customers, organizational sources, as it will reduce the common method variance.
For example, while implicit voice theories are asked to the employees, their voicing or silence behaviors can be asked to their managers or coworkers.

Another limitation of this study is that we only examined the two sub-dimensions of implicit voice theories, constructive employee voice and defensive employee silence to avoid the long survey format. We collected data at one-point time and therefore, participants were not eager to reply a survey with many items. We had to exclude the items of three sub-dimensions of implicit voice theories. We also could not include the other sub-dimensions of employee voice and employee silence. We recommend to future researchers to examine the implicit voice theories, employee voice and employee silence with their all sub-dimensions, which will enable them to analyze these constructs in a more comprehensive way. Finally, convenience sampling method was used to collect data. Future researchers are also recommended to replicate this study using randomize sampling methods.

\section{Conclusion}

In social life, individuals will constantly perceive their environment, form beliefs, and react to their environment in the light of these beliefs. Under the influence of the beliefs formed by the information they have obtained, they will form a common attitude. Employees' beliefs about the conditions of their organization greatly affect their attitude towards the organization. If employees share negative beliefs and attitudes towards speaking up, organizational performance will be greatly affected because many employees in the organization may choose to remain silent due to the fear of social exclusion, punishment or retaliation. This situation prevents the employees from expressing their ideas openly and honestly. Despite their self-confidence, employees consider it risky to participate in discussions, to speak openly, and to express opinions and views on issues related to the organization. Therefore, it is important to examine these beliefs, which are one of the reasons for organizational silence.

\section{Acknowledgement}

This study has been developed by training and activities organized within the scope of TUBITAK 4005 project numbered 118B056.

\section{Compliance with Ethical Standards}

Ethical approval for this study was obtained to Ethical Committee of Medeniyet University (Date: 03 April 2018, Number: 14725836-050.04.04-E.5379). 


\section{Literature}

Ajay K. J., (2015). An interpersonal perspective to study silence in Indian organizations, Personnel Review, 44(6), 1010 - 1036, http://dx.doi.org/10.1108/PR-122013-0220

Akın, A. \& Arıcı, N. (2015). Turkish Version of Proactive Scale: A study of validity and reliability. Mevlana International Journal of Education (MIJE), 5(1), 165172. http://dx.doi.org/10.13054/mije.14.12.5.1

Alparslan, A. M., Can, A., \& Erdem, R. (2015). Reasons for employee silence behavior: Developing and validating a scale for nurses. Hacettepe Săg $l ı k$ İdaresi Dergisi, 18(2), 183-204.

Amah, O. E., \& Oyetuunde, K. (2020). The effect of servant leadership on employee turnover in SMEs in Nigeria: the role of career growth potential and employee voice. Journal of Small Business and Enterprise Development. 27(6), 885-904. https://doi.org/10.1108/ JSBED-01-2019-0009

Antonakis, J., Bendahan, S., Jacquart, P., \& Lalive, R. (2010). On making causal claims: A review and recommendations. The Leadership Quarterly, 21(6), 10861120. https://doi.org/10.1016/j.leaqua.2010.10.010

Arıkan, S. (2011). İşyerinde kullanılan politik taktiklere yönelik olası bireysel önceller üzerine bir araştırma [A Study on Probable Individual Antecedents of Workplace Political Tactics]. Türk Psikoloji Dergisi, 26(68), 52-71. Retrieved from: https:// www.psikolog.org.tr/tr/yayinlar/dergiler/1031828/ tpd1300443320110000m000089.pdf

Bacon, D. R., Sauer, P. L., \& Young, M. (1995). Composite reliability in structural equations modeling. Educational and Psychological Measurement, 55(3), 394-406. https://doi.org/10.1177/0013164495055003003

Bakker, A. B., M. Tims, \& D. Derks. (2012). Proactive Personality and Job Performance: The Role of Job Crafting and Work Engagement. Human Relations, 65(10), 13591378. https://doi.org/10.1177/0018726712453471

Bateman, T. S., \& Crant, J. M. (1993). The proactive component of organizational behavior: A measure and correlates. Journal of Organizational Behavior, 14, 103118. https://doi.org/10.1002/job.4030140202

Bayramoglu, D., \& Cetinkanat, C. A. (2020). Examining the Relationship between Organizational Commitment and Organizational Silence of Teachers. Revista de Cercetare si Interventie Sociala, 71, 25-40. https://doi. org/10.33788/rcis. 71.2

Bilgetürk, M., \& Baykal, E. (2021). How does perceived organizational support affect psychological capital? The mediating role of authentic leadership. Organizacija, 54(1), 82-95. https://doi.org/10.2478/orga2021-0006

Bolino, M., Valcea, S., \& Harvey, J. (2010). Employee, manage thyself: The potentially negative implications of expecting employees to behave proactively. Journal of Occupational and Organizational Psychology, 83(2), 325-345. https://doi.org/10.1348/096317910X493134

Bowen, F., \& Blackmon, K. (2003). Spirals of silence: The dynamic effects of diversity on organizational voice. Journal of Management Studies, 40(6), 1393-1417. https://doi.org/10.1111/1467-6486.00385

Breevaart, K., Bohle, S. L., Pletzer, J. L., \& Medina, F. M. (2020). Voice and silence as immediate consequences of job insecurity. Career Development International. 25(2), 204-220, https://doi.org/10.1108/CDI-09-20180226

Brislin, R. W. (1970). Back-translation for cross-cultural research. Journal of Cross-Cultural Psychology, 1(3), 185-216. http://doi.org/10.1177/135910457000100301

Çankır, B. (2016). Çalışanlarda pozitif ses çıkartma davranış1 nasıl oluşur? Örgütsel güven, psikolojik sözleşme ihlali, lider-üye etkileşimi ile pozitif ses çıkartma davranışı arasındaki ilişkinin incelenmesi [How Do Voice Behavior On Employees? An Application to Correlations Between Organizational Trust, Psychological Contract Violation, Leader-Member Exchange and Positive Voice Behavior]. Kirklareli Üniversitesi İktisadi ve İdari Bilimler Fakültesi Dergisi, 5(2), 1-12. Retrieved from: https://dergipark.org.tr/ en/pub/klujfeas/issue/26889/283218.

Chamberlin, M., Newton, D. W., \& Lepine, J. A. (2017). A meta-analysis of voice and its promotive and prohibitive forms: Identification of key associations, distinctions, and future research directions. Personnel Psychology, 70(1), 11-71. https://doi.org/10.1111/ peps. 12185

Cheng, Y., Nudelman, G., Otto, K., \& Ma, J. (2020). Belief in a Just World and Employee Voice Behavior: The Mediating Roles of Perceived Efficacy and Risk. The Journal of Psychology, 154(2), 129-143. https://doi.or $\mathrm{g} / 10.1080 / 00223980.2019 .1670126$

Chou, S. Y., \& Chang, T. (2020). Employee silence and silence antecedents: A theoretical classification. International Journal of Business Communication, 57(3), 401-426. https://doi.org/10.1177/2329488417703301

Cooper, C. A. (2018). Encouraging civil servants to be frank and fearless: Merit recruitment and employee voice. Public Administration, 96(4), 721-735. https:// doi.org/10.1080/1359432X.2020.1733979.

Crant, J. M. (2000). Proactive behavior in organizations. Journal of Management, 26(3), 435-462. https://doi. org/10.1177/014920630002600304

Cronbach, L. J. (1951). Coefficient alpha and the internal structure of tests. Psychometrika, 16(3), 297-334. https://doi.org/10.1007/BF02310555

Detert, J. R., \& Burris, E. R. (2007). Leadership behavior and employee voice: Is the door really open?. Academy of Management Journal, 50(4), 869-884. https:// doi.org/10.5465/AMJ.2007.26279183 
Detert, J. R., \& Edmondson, A. C. (2011). Implicit voice theories: Taken-for-granted rules of self-censorship at work. Academy of Management Journal, 54(3), 461488. https://doi.org/10.5465/amj.2011.61967925

Dyne, L. V., Ang, S., \& Botero, I. C. (2003). Conceptualizing employee silence and employee voice as multidimensional constructs. Journal of Management Studies, 40(6), 1359-1392. https://doi. org/10.1111/1467-6486.00384

Engle, E. M., \& Lord, R. G. (1997). Implicit theories, self-schemas, and leader-member exchange. Academy of Management Journal, 40(4), 988-1010. https://doi. org $/ 10.2307 / 256956$

Erdoğan, E. (2011). Örgütsel Sessizlik ve Performans İlişkisi [Organizational Silence and Its Relation with Performance]. Unpublished Master Thesis. Gebze İleri Teknoloji Enstitüsü Sosyal Bilimler Enstitüsü.

Ergül, S., \& Söyük, S. (2020). The effect of leadership behaviors on organizational silence: The case of two public hospitals. Nobel Medicus, 16(1): 47-55. Retrieved from: https://www.nobelmedicus.com/Content/1/46/47-55.pdf

Fornell, C., \& Larcker, D. F. (1981). Evaluating structural equation models with unobservable variables and measurement error. Journal of Marketing Research, 18(1), 39-50. https://doi.org/10.2307/3151312

Glassenberg, A. N. (2012). Exploring implicit voice theories at work (Order No. 3514405). Available from ProQuest Dissertations \& Theses Global. (1027935436). Retrieved from https://search.proquest. com/dissertations-theses/exploring-implicit-voice-theories-at-work/docview/1027935436/se-2?accountid $=146364$.

Hair Jr., J.F., Black, W.C., Babin, B.J. and Anderson, R.E. (2010) Multivariate Data Analysis: A Global Perspective. 7th Edition, Pearson Education, Upper Saddle River. London: Pearson.

Harmanci Seren, A. K., Topcu, İ., Eskin Bacaksiz, F., Unaldi Baydin, N., Tokgoz Ekici, E., \& Yildirim, A. (2018). Organisational silence among nurses and physicians in public hospitals. Journal of Clinical Nursing, 27(7-8), 1440-1451. https://doi.org/10.1111/jocn.14294

Hofstede, G. (1983). The cultural relativity of organizational practices and theories. Journal of international business studies, 14(2), 75-89. https://doi.org/10.1057/ palgrave.jibs. 8490867

Huang, X., Van de Vliert, E., \& Van der Vegt, G. (2005). Breaking the silence culture: Stimulation of participation and employee opinion withholding cross-nationally. Management and Organization Review, 1(3), 459482.

https://doi.org/10.1111/j.1740-8784.2005.00023.x

Isaakyan, S. (2018). Public versus Private Voice: The Role of Social Setting in Explaining Managerial Reactions to Employee Voice. Datawyse / Universitaire Pers Maastricht. https://doi.org/10.26481/dis.20180601si

Kline, R. B. (2016). Principles and Practice of Structural Equation Modelling, 4th edn. New York: Guilford Press. https://www.guilford.com/books/Principles-and-Practice-ofStructural-Equation-Modeling/ Rex-Kline/9781462523344.

Knoll, M., Neves, P., Schyns, B., \& Meyer, B. (2020). A multi-level approach to direct and indirect relationships between organizational voice climate, team manager openness, implicit voice theories, and silence. Applied Psychology: An International Review, https://doi. org/10.1111/apps. 12242

Lee, G. L., Diefendorff, J. M., Kim, T. Y., \& Bian, L. (2014). Personality and participative climate: Antecedents of distinct voice behaviors. Human Performance, 27(1), 25-43. https://doi.org/10.1080/08959285.2013. 854363

LePine, J. A., \& Dyne, L. (2001). Voice and cooperative behavior as contrasting forms of contextual performance: Evidence of differential relationships with Big Five personality characteristics and cognitive ability. Journal of Applied Psychology, 86(2), 326-336. https://doi.org/10.1037/0021-9010.86.2.326

Liang, J., Farh, C. I., \& Farh, J. L. (2012). Psychological antecedents of promotive and prohibitive voice: A twowave examination. Academy of Management Journal, 55(1), 71-92. https://doi.org/10.5465/amj.2010.0176

Maynes, T. D., \& Podsakoff, P. M. (2014). Speaking more broadly: An examination of the nature, antecedents, and consequences of an expanded set of employee voice behaviors. Journal of Applied Psychology, 99(1), 87-12. https://doi.org/10.1037/a0034284

Milliken, F. J., Morrison, E. W., \& Hewlin, P. F. (2003). An exploratory study of employee silence: Issues that employees don't communicate upward and why. Journal of Management Studies, 40(6), 1453-1476. https://doi. org/10.1111/1467-6486.00387

Morrison E. W. \& Rothman N. B. (2009). Silence and the dynamics of power. In Greenberg J, Edwards MJ (Eds.), Voice and Silence in Organizations (pp. 111134). Bingley, UK: Emerald.

Morrison, E. W., \& Milliken, F. J. (2000). Organizational silence: A barrier to change and development in a pluralistic world. Academy of Management Review, 25(4), 706-725. https://doi.org/10.2307/259200

Morrison, E.W. (2014). Employee voice and silence. Annual Review of Organizational Psychology and Organizational Behavior, 1, pp. 173-197. https://doi. org/10.1146/annurev-orgpsych-031413-091328

Pierce, J. L., \& Gardner, D. G. (2004). Self-esteem within the work and organizational context: A review of the organization-based self-esteem literature. Journal of Management, 30(5), 591-622. https://doi. 
org/10.1016/j.jm.2003.10.001

Pinder, C., \& Harlos, K. (2001). Employee silence: Quiescence and acquiescence as responses to perceived injustice. In G. Ferris (Ed.), Research in personnel and human resources management (Vol. 20, pp. 331-369). Greenwich, CT: JAI Press.

Pirzada, Z. A., Mirani, S. H., Phulpoto, N. H., Dogar, H., \& Mahar, S. A. (2020). Study of Employee silence, Organizational Justice and Work Engagement: Mediation Analysis. IJCSNS, 20(1), 9-14. Retrieved from: http:// paper.ijcsns.org/07_book/202001/20200102.pdf

Podsakoff, P. M., MacKenzie, S. B., Lee, J. Y., \& Podsakoff, N. P. (2003). Common method biases in behavioral research: A critical review of the literature and recommended remedies. Journal of Applied Psychology, 88(5), 879-903. https://psycnet.apa.org/ doi/10.1037/0021-9010.88.5.879

Sadeghi, M., \& Razavi, M. R. (2020). Organizational silence, organizational commitment and creativity: The case of directors of Islamic Azad University of Khorasan Razavi. European Review of Applied Psychology, 70(5), 100557. https://doi.org/10.1016/j. erap. 2020.100557

Seibert, S. E., Crant, J. M., \& Kraimer, M. L. (1999). Proactive personality and career success. Journal of Applied Psychology, 84(3), 416-427. https://doi. org/10.1037/0021-9010.84.3.416

Seibert, S. E., Kraimer, M. L., \& Crant, J. M. (2001). What do proactive people do? A longitudinal model linking proactive personality and career success. Personnel Psychology, 54(4), 845-874. https://doi. org/10.1111/j.1744-6570.2001.tb00234.x

Sherf, E. N., Parke, M. R., \& Isaakyan, S. (2020). Distinguishing voice and silence at work: unique relationships with perceived impact, psychological safety, and burnout. Academy of Management Journal, https://doi. org/10.5465/amj.2018.1428.

Singh, K., Singh, J., Ahmad, N. B., Singh, S., \& Kaur, D. (2020). Dimensions of Organizational Silence and Intention to Leave. A Quantitative Study among Generation Y Employees in the Private Sector in Jakarta, Indonesia. International Journal of Psychosocial Rehabilitation, 24(2), 952-967. https://doi.org/ 10.37200/ IJPR/V24I2/PR200403

Starbuck, C. R. (2016). Managing insidious barriers to upward communication in organizations: An empirical investigation of relationships among implicit voice theories, power distance orientation, self-efficacy, and leader-directed voice (Order No. 10017974). Available from ProQuest Central; ProQuest Dissertations \& Theses Global. (1767788721). Retrieved from https://search.proquest.com/dissertations-theses/ managing-insidious-barriers-upward-communication/ docview/1767788721/se-2?accountid=146364.
Takhsha, M., Barahimi, N., Adelpanah, A., \& Salehzadeh, R. (2020). The effect of workplace ostracism on knowledge sharing: the mediating role of organization-based self-esteem and organizational silence. Journal of Workplace Learning. 32(6), 417-435. https://doi. org/10.1108/JWL-07-2019-0088

Tedone, A. M., \& Bruk-Lee, V. (2021). Speaking up at work: personality's influence on employee voice behavior. International Journal of Organizational Analysis. Ahead of print, https://doi.org/10.1108/IJOA-092020-2417

Under, I., \& Gerede, E. (2021). Silence in Aviation: Development and Validation of a Tool to Measure Reasons for Aircraft Maintenance Staff not Reporting. Organizacija, 54(1), 3-16. https://doi.org/10.2478/orga-20210001

Wijaya, N. H. S. (2019). Proactive personality, LMX, and voice behavior: employee-supervisor sex (Dis) similarity as a moderator. Management Communication Quarterly, 33(1), 86-100.

https://doi.org/10.1177/0893318918804890

Willemsma, T. A. (2014). Encouraging work group voice: exploring how interventions can contribute to developments in work group voice (Master's thesis, University of Twente). Retrieved from: http://purl.utwente.nl/ essays/65796.

Xu, Q., Zhao, Y., Xi, M., \& Li, F. (2020). Abusive supervision, high-performance work systems, and subordinate silence. Personnel Review, 49(8), 1637-1653. https:// doi.org/10.1108/PR-01-2019-0029

Yeager, D. S., \& Dweck, C. S. (2012). Mindsets that promote resilience: When students believe that personal characteristics can be developed. Educational Psychologist, 47(4), 302-314. http://dx.doi.org/10.1080/0 0461520.2012 .722805

Yoo, W., Mayberry, R., Bae, S., Singh, K., He, Q., \& Lillard Jr., J. (2014). A study of effects of multicollinearity in the multivariable analysis. International Journal of Applied Science and Technology, 4(5), 9-19. Retrieved from: https://www.ncbi.nlm.nih.gov/pmc/articles/PMC4318006/\# ffn_sectitle

Zhan, M. (2020). When to speak up at work: a review of employee voice and silence behavior using a prospect approach. Atlantic Journal of Communication, 28(5), 273-288. https://doi.org/10.1080/15456870.2020.172 0682 
Safiye Şahin is currently working at Department of Health Management in Istanbul Medeniyet University as an Assistant Professor. She completed her Ph.D. at the Department of Management and Organization in Marmara University in 2016. Her research areas are healthcare management and organizational behavior, especially employee silence and voice, work-family issues, work engagement, and job performance. https://orcid.org/0000-0003-1734-9586

Bilal Çankır, Ph.D., is an Associate Professor at Faculty of Health Sciences, Department of Health Management in Istanbul Medeniyet University, Turkey. His research interest mostly concentrates on organizational behavior, strategic management and human resources management. He has many national and international publications in these fields. http:// orcid.org/0000-0001-5126-8769
Bahar Serez Arslan, M.Sc., is working as a lecturer in Health Sciences Vocational School at Kırklareli University. She is teaching courses of medical documentation and secretary at undergraduate level. Her research areas are public management and healthcare management. https://orcid.org/0000-00033863-0190 